\title{
Severe visceral leishmaniasis in children: the relationship between cytokine patterns and clinical features
}

\author{
Mônica Elinor Alves Gama ${ }^{[1]}$, Cláudia Maria de Castro Gomes ${ }^{[2]}$, \\ Fernando Tobias Silveira ${ }^{[3,4]}$, Márcia Dalastra Laurenti ${ }^{[2]}$, \\ Eloisa da Graça Gonçalves ${ }^{[5]}$, Antônio Rafael da Silva ${ }^{[5]}$ \\ and Carlos Eduardo Pereira Corbett ${ }^{[2]}$
}

\begin{abstract}
1]. Departamento de Medicina III, Centro de Ciências da Saúde, Universidade Federal do Maranhão, São Luís, MA. [2]. Departamento de Patologia, Faculdade de Medicina da Universidade de São Paulo, São Paulo, SP. [3]. Instituto Evandro Chagas, Ananideua, Belém, Pará. [4]. Núcleo de Medicina Tropical, Universidade Federal do Pará, Belém, PA. [5]. Departamento de Patologia, Centro de Ciências da Saúde, Universidade Federal do Maranhão, São Luís, MA.
\end{abstract}

\begin{abstract}
Introduction: The relationship between severe clinical manifestations of visceral leishmaniasis (VL) and immune response profiles has not yet been clarified, despite numerous studies on the subject. This study aimed to investigate the relationship between cytokine profiles and the presence of immunological markers associated with clinical manifestations and, particularly, signs of severity, as defined in a protocol drafted by the Ministry of Health (Brazil). Methods: We conducted a prospective, descriptive study between May 2008 and December 2009. This study was based on an assessment of all pediatric patients with VL who were observed in a reference hospital in Maranhão. Results: Among 27 children, 55.5\% presented with more than one sign of severity or warning sign. Patients without signs of severity or warning signs and patients with only one warning sign had the highest interferon-gamma (IFN- $\gamma$ ) levels, although their interleukin 10 (IL-10) levels were also elevated. In contrast, patients with the features of severe disease had the lowest IFN- $\gamma$ levels. Three patients who presented with more than two signs of severe disease died; these patients had undetectable interleukin 2 (IL-2) and IFN- $\gamma$ levels and low IL-10 levels, which varied between 0 and $36.8 \mathrm{pg} / \mathrm{mL}$. Conclusions: Our results showed that disease severity was associated with low IFN- $\gamma$ levels and elevated IL-10 levels. However, further studies with larger samples are needed to better characterize the relationship between disease severity and cytokine levels, with the aim of identifying immunological markers of active-disease severity.
\end{abstract}

Keywords: Visceral leishmaniasis. Kala-azar. Systemic inflammatory response syndrome. Cytokine production.

\section{INTRODUCTION}

Visceral leishmaniasis (VL), which is endemic throughout Brazil, can be lethal if not treated quickly because it is systemic in nature. In addition to its persistence, a progressive spreading of the disease to new areas has been observed, and the associated lethality has increased in various regions of the country ${ }^{1-3}$. In 1994 , the incidence of lethality was $3.4 \%$; in 2003 , the lethality reached $8.5 \%$; and in 2009 , the lethality was $5.8 \%{ }^{3,4}$.

The occurrence of death from VL is associated with several factors, including young age and the presence of comorbidities such as infections, malnutrition, and AIDS. The following features have been cited as markers of poor prognosis: fever lasting for more than 60 days, bacterial infection, jaundice,

\footnotetext{
Address to: Drª Mônica Elinor Alves Gama. Av. Castelo Branco 605, 65076-090 São Luís, MA, Brasil.

Phone: 5598 3216-9900

e-mail: mgama@elo.com.br; academico@faculdadelaboro.com.br

Received 3 October 2013

Accepted 5 December 2013
}

dyspnea, hemorrhage, severe anemia, severe neutropenia, and thrombocytopenia ${ }^{3-11}$. In addition, difficulties in early diagnosis and appropriate treatment administration in many endemic areas are other determining factors of lethality; these issues are mainly caused by restricted access to health services ${ }^{4}$.

Much knowledge has been gained on the immunopathogenesis of VL. As the parasites multiply within splenic, liver, and bone marrow macrophages, the pathogens induce strong activation of the patient's mononuclear phagocyte system. High interferongamma (IFN- $\gamma$ ) and tumor necrosis factor alpha (TNF- $\alpha$ ) levels are then detected, and these cytokines may control parasite proliferation during the early stages. However, despite a highly activated immune system, patients exhibit Leishmania antigenspecific immunosuppression ${ }^{12}$. Additionally, interleukin 10 (IL-10) and TGF- $\beta$ activity in splenic and liver macrophages induces parasite proliferation; therefore, these cytokines can be characterized as immune response regulators ${ }^{13-18}$. It has been suggested that the main risk factors for death in VL are related to the fact that such high systemic pro-inflammatory cytokine production greatly compromises organs and systems ${ }^{10}$.

Although significant advances have been made in the understanding of different aspects of VL, effective disease control has not yet been achieved due to its clinical and 
epidemiological complexity; in fact, lethality has increased in several regions of the country ${ }^{2}$. In 2011, when faced with the serious situation of increasing VL lethality, the Ministry of Health (Brazil) initiated a therapeutic clinical protocol to identify and follow patients who were at greater risk of progression to severe VL or who already displayed signs of severity. This protocol will undoubtedly facilitate the appropriate follow-up of cases and a gradual reduction in lethality ${ }^{3}$.

The current study aimed to investigate the relationship between clinical manifestations, and particularly signs of severity, as defined in the protocol drafted by the Ministry of Health (Brazil), and IL-2, IFN- $\gamma$, and IL-10 profiles in peripheral blood from pediatric patients who were observed at the Infectious and Parasitic Diseases Reference Center in the State of Maranhão. This study contributes to the understanding of the immunological factors associated with disease severity, with the intent of reducing mortality.

\section{METHODS}

A prospective, descriptive study was conducted between May 2008 and December 2009. This study was based on the assessment of all pediatric patients with VL from several municipalities of Maranhão who were treated in the outpatient and inpatient centers at the University Hospital of the Federal University of Maranhão.

The Maternal Child Hospital of the Federal University of Maranhão is a tertiary reference hospital for the entire state that has a center that specializes in the care of patients with infectious and parasitic diseases. Numerous areas in the state of Maranhão exhibit endemic and epidemic VL patterns, particularly in the peripheral urban areas of municipalities, such as São Luis, Paço do Lumiar, São José de Ribamar, Caxias, Raposa, and Imperatriz. In these areas, there are massive infestations with Lutzomyia longipalpis in and around homes and a growing incidence of human and canine VL cases.

The inclusion criteria were as follows: children between 0 and 13 years of age who were observed in the Department of Infectious and Parasitic Diseases of the Maternal Child Hospital of the Federal University of Maranhão (HUMIUFMA) and who had a confirmed (detection of Leishmania in bone marrow aspirate) or suspected VL (epidemiological, clinical, and nonspecific laboratory findings and serological results suggestive of VL) diagnosis ${ }^{3,4}$, active disease, cytokine assay results from at least one stage during follow-up (before or during treatment), and an informed consent form signed by a parent/guardian.

In total, 27 patients were included in the study, and only three had a suspected VL diagnosis. Information regarding the patients' personal data, clinical manifestations, laboratory abnormalities, previous treatments (specific or nonspecific), and cytokine profiles were recorded on file. Following the characterization of their clinical and epidemiological VL profiles, the patients underwent bone marrow punctures for Leishmania detection (bone marrow examination). Additionally, serological diagnoses (qualitative enzyme-linked immunosorbent assay ELISA) and nonspecific tests were performed, and peripheral blood cytokine levels (IL-2, IFN- $\gamma$, and IL-10) were measured with a Quantikine Immunoassay ELISA kits (R\&D Systems, Minneapolis, MN, USA).

The determination of cytokine levels in the sera of VL patients $(n=27)$ and controls $(n=10)$ was conducted using a quantitative sandwich ELISA technique (R\&D Systems, Minneapolis, MN, USA) for human IL-2 (Catalog Number D2050), human IFN- $\gamma$ (Catalog Number DIF50), and human IL-10 (Catalog Number D1000B) according to the manufacturer's instructions.

The data were recorded and analyzed with the statistical software Epi Info, version 2000 (Centers for Disease Control; available at http://wwwn.cdc.gov/epiinfo/). A descriptive data analysis was performed, and clinical manifestations and laboratory abnormalities were classified into the following categories, as defined by the protocol drafted by the Ministry of Health ${ }^{3,4}$ : I) Children with signs of severity. This category includes patients younger than 6 months of age and those with comorbidities or one of the following clinical manifestations: jaundice, hemorrhage (except for epistaxis), generalized edema, and signs of toxemia (lethargy, poor perfusion, cyanosis, tachycardia, or bradycardia; hypoventilation or hyperventilation; and hemodynamic instability); II) Children with warning signs (indicators of potential severity). This category includes patients aged 6 months to 1 year and those with relapse, diarrhea, vomiting, suspected bacterial infection, or fever for more than 60 days.

\section{Ethical considerations}

This project was approved by the Research Ethics Committee of the Federal University of Maranhão and the Faculty of Medicine, University of São Paulo (protocol number 0255/2007), in accordance with Resolution 196/96 of the National Health Council regarding research involving human beings.

\section{RESULTS}

First, data on the clinical manifestations and abnormal laboratory values that facilitated the classification of the 27 children into the group with signs of severity and the group with warning signs were examined. Notably, $55.5 \%$ of the cases presented with more than one sign of severity or warning sign (Table 1).

Four children were younger than 6 months of age, and three children were aged between 6 months and 1 year; the ages of the remaining children ranged from 1-8 years. The clinical manifestations and laboratory abnormalities that defined the signs of severity and warning signs are described in Table 2. Notably, fever was characterized by daily intermittent episodes, which were moderate in most $(74.1 \%)$ cases; fever for more than 60 days was reported in only one case. Splenomegaly was severe in more than $80 \%$ of the children, and hepatomegaly was moderate in $77.8 \%$ of the cases. Notably, $63 \%$ of the patients were diagnosed with bacterial infections based on the clinical and laboratory signs of infection. 
TABLE 1 - Classifications of clinical manifestations and laboratory abnormalities in 27 children with visceral leishmaniasis according to severity and warning criteria at the Maternal Child Hospital, Federal University of Maranhão, 2009.

\begin{tabular}{lcc}
\hline Classification & Number & Percentage \\
\hline No signs of severity or warning signs & 3 & 11.1 \\
\hline With signs of severity & 7 & 25.9 \\
$\quad$ one sign & 9 & 33.3 \\
two or more signs & 16 & 59.2 \\
$\quad$ total & 2 & \\
\hline With warning signs & 6.4 \\
$\quad$ one sign & 6 & 22.2 \\
two or more signs & 8 & 29.6 \\
$\quad$ total & 27 & 100.0 \\
\hline Total & & \\
\hline
\end{tabular}

The cytokine analysis showed that only two (7.4\%) patients had detectable IL-2 levels (mean, $15.33 \mathrm{pg} / \mathrm{mL}$ ); one of these patients had more than two signs of severity. Eleven (40.7\%) patients had detectable IFN- $\gamma$ levels before starting treatment (mean, $77.31 \mathrm{pg} / \mathrm{mL}$; range, $12.62-244.6 \mathrm{pg} / \mathrm{mL}$ ). Additionally, most $(70.4 \%)$ patients had detectable IL-10 levels (mean, $91.87 \mathrm{pg} / \mathrm{mL}$; range, $9.9-394.2 \mathrm{pg} / \mathrm{mL}$ ).

Table 3 shows the relationship between the presence of signs of severity or warning signs and detectable cytokine serum levels before treatment administration. Patients without signs of severity or warning signs and those with only one warning sign exhibited the highest levels of IFN- $\gamma$, although their IL-10 levels were also elevated. In contrast, patients with signs of severity had the lowest IFN- $\gamma$ levels.

Three patients with more than two signs of severity died. The cytokine profiles of these patients were as follows: undetectable levels of IL-2 and IFN- $\gamma$ and low levels of IL-10 (mean, $11.46 \mathrm{pg} / \mathrm{mL}$; range, $9.9-12.5 \mathrm{pg} / \mathrm{mL}$ ).

\section{DISCUSSION}

The diagnosis and treatment protocols for severe cases of VL, as proposed by the Brazilian Ministry of Health in 2006, are expected to help to reduce VL lethality, In particular, the definition of severity and warning criteria provides health professionals with guidelines regarding the appropriate actions to be taken ${ }^{3,4}$. The results of the present study show that the management of patients who are admitted to the HUMI-UFMA at the Federal University of Maranhão, which is an important secondary and tertiary reference center for VL across the entire State of Maranhão, is complex.

VL patients' clinical manifestations and laboratory abnormalities permit the diagnosis of the most severe cases and cases at greater risk of disease progression ${ }^{8,17,18}$. Our clinical and laboratory findings agree with those reported by previous
TABLE 2 - Clinical manifestations and laboratory abnormalities in 27 patients with visceral leishmaniasis at the Maternal Child Hospital, Federal University of Maranhão, 2009.

\begin{tabular}{|c|c|}
\hline Clinical and laboratory findings & Percentage \\
\hline \multicolumn{2}{|l|}{ Clinical manifestations } \\
\hline fever & 100.0 \\
\hline splenomegaly & 100.0 \\
\hline hepatomegaly & 85.2 \\
\hline paleness & 81.5 \\
\hline signs of toxemia & 37.1 \\
\hline hemorrhage & 33.3 \\
\hline diarrhea & 33.3 \\
\hline suspected infection & 25.9 \\
\hline generalized edema & 22.2 \\
\hline jaundice & 18.5 \\
\hline localized edema & 14.8 \\
\hline \multicolumn{2}{|l|}{ Laboratory abnormalities } \\
\hline $\begin{array}{l}\text { leukopenia }\left(\mathrm{M}=1.004 \mathrm{leuc} / \mathrm{mm}^{3}\right) \\
\text { with neutropenia }\left(\mathrm{M}=367 \mathrm{neut} / \mathrm{mm}^{3}\right)\end{array}$ & 88.9 \\
\hline severe anemia $(\mathrm{Hb} \mathrm{M}=4.3 \mathrm{~g} / \mathrm{dL})$ & 77.8 \\
\hline thrombocytopenia $\left(\mathrm{M}=69 \mathrm{mil} / \mathrm{mm}^{3}\right)$ & 74.1 \\
\hline $\begin{array}{l}\text { elevated liver enzyme levels (ALT) } \\
M=326 \mathrm{U} / \mathrm{L} \text {; AST } \mathrm{M}=214 \mathrm{U} / \mathrm{L} \text { ) }\end{array}$ & 74.1 \\
\hline hypoalbuminemia $(\mathrm{M}=1.5 \mathrm{~g} / \mathrm{dL})$ & 70.4 \\
\hline hypergammaglobulinemia $(\mathrm{M}=6.8 \mathrm{~g} / \mathrm{dL})$ & 93.4 \\
\hline altered coagulogram (prothrombin activation & \\
\hline time $M=47 \%$ ) & 51.8 \\
\hline elevated creatinine levels $(\mathrm{M}=1.7 \mathrm{mg} / \mathrm{dL})$ & 25.9 \\
\hline
\end{tabular}

AST: aspartate transaminase; ALT: alanine aminotransferase; $\mathrm{Hb}$ : haemoglobin; M: mean.

studies, as a combination of fever, hepatosplenomegaly, anemia, and leukopenia was frequently observed and led to the suspicion of VL in such cases, particularly in children ${ }^{19}$.

Many studies have demonstrated multiple causes of death and have identified clinical risk factors as important predictive markers ${ }^{9,10,20,21}$. The host immunological response to the parasite is certainly a major clinical determinant in $\mathrm{VL}^{10,22}$.

The activation of $\mathrm{CD} 4+\mathrm{T}$ cells and the differentiation of these cells into Th1 or Th2 effector cells are crucial to the development of resistance or susceptibility to Leishmania infection ${ }^{23}$. However, studies have shown that there is no dichotomy in the production of cytokines in VL, but rather a predominance of elevated levels of a pool of cytokines ${ }^{17,18,24,25}$.

To the best of our knowledge, no previous study has examined the association between clinical features, particularly 
TABLE 3 - Relationship between the presence of signs of severity or warning signs and detected cytokine levels at the Maternal Child Hospital, Federal University of Maranhão, 2009.

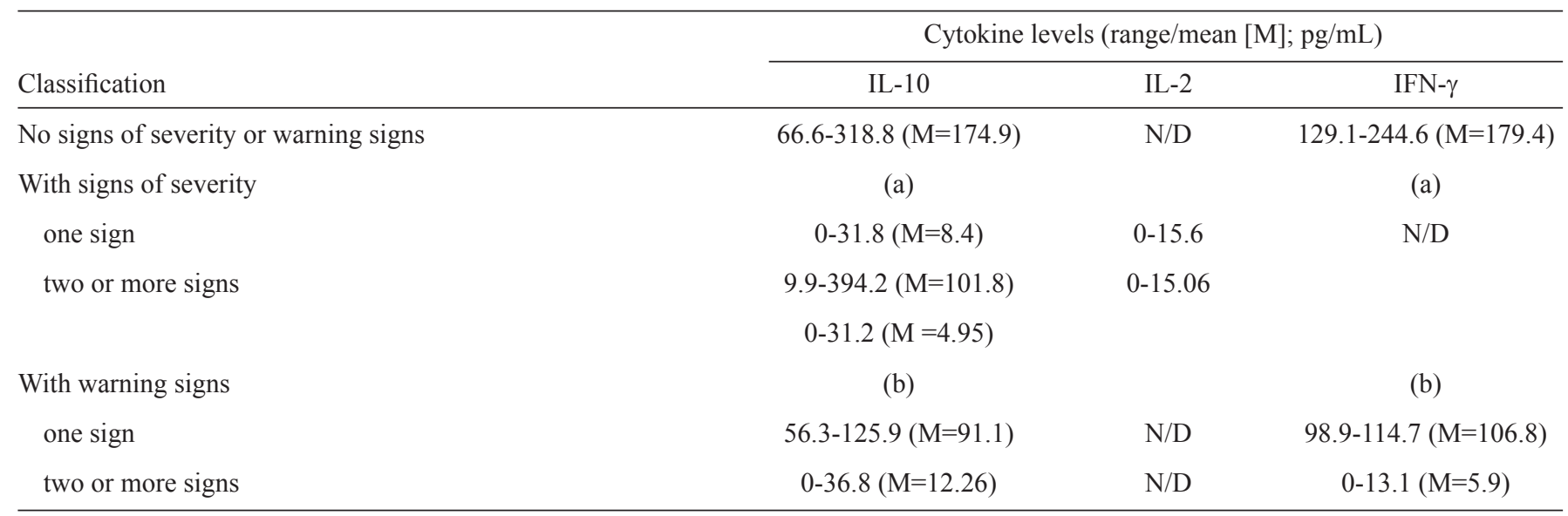

M: mean; IL-10: Interleukin 10; IL-2: Interleukin 2; IFN- $\gamma$ : inferferon-gamma; N/D: none detected. (a): p $<0.05$ between the No signs of severity or warning signs group and the With signs of severity group (with one or two or more signs); (b): $\mathrm{p}<0.05$ between the $B s$ group and the With warning signs group (with one or two or more signs).

the signs of severity and the warning signs, as defined by the protocol of the Ministry of Health ${ }^{3,4}$, and cytokine profiles in active VL. In the present study, patients without signs of severity and those with only one warning sign had high IFN- $\gamma$ levels and elevated IL-10 levels. This finding suggests that an immune balance is sought to achieve control over active disease. This hypothesis is reinforced by the observation that patients with signs of severity exhibited lower IFN- $\gamma$ levels.

IFN- $\gamma$ involvement is key to the host defense mechanism against VL. IFN- $\gamma$ activates macrophages, leading to inducible nitric oxide synthase activation and concomitant nitric oxide production, which promotes parasite death ${ }^{26,27}$. Recently, the pro-inflammatory cytokine IL-17 was also reported to have a protective role in $L$. donovani-induced $\mathrm{VL}^{28}$ and in experimental $L$. (L.) chagasi infections by acting synergistically with IFN- $\gamma$ to eliminate the parasite ${ }^{29}$.

Studies conducted in an endemic area in northeastern Brazil on $L$. (L.) chagasi-infected individuals without active disease characterized the immune response to Leishmania antigens during early stage infection ${ }^{30}$. Early immune changes were observed during infection, and an association was noted among absent or low lymphocyte proliferation, low IFN- $\gamma$ production, and progression from infection to disease ${ }^{31,32}$. These changes were associated with IL-10 production because the in vitro addition of anti-IL-10 reversed the changes $^{31-33}$. These studies contributed to the identification of IL-10 as an important mediator of the immunological changes observed in VL, as IL-10 could also block the in vitro effects of IL-12, a cytokine that plays a central role in Th1 effector cell differentiation ${ }^{34}$.

More recent findings indicated a close relationship among IL-10 production, host susceptibility, and VL exacerbation ${ }^{35-37}$. Additionally, IL-10 is considered to be an immunoregulatory cytokine because it has a negative effect on lymphocyte proliferation ${ }^{33,37}$. Regulatory $\mathrm{T}$ (Treg) cells are well-characterized cells that act as an important source of such suppressor cytokines. In particular, Treg cells mediate the suppression of innate and acquired immune cells by secreting IL-10 and TGF- $\beta$ and by cell-cell contact ${ }^{38,39}$. Given that Treg cells are a primary source of IL-10, these cells may also be involved in the pathogenesis of active VL.

Elevated IL-10 levels that are not balanced by equally elevated levels of IFN- $\gamma$ could explain the occurrence of the most severe VL cases observed in our study.

Our results show that regardless of disease severity, IL-10 was present in patient sera, although low levels of IFN- $\gamma$ were associated with VL severity in children. Further studies with larger samples are needed to better characterize the relationship between VL severity and cytokine levels and to clarify the immunopathogenesis of the clinical manifestations and laboratory abnormalities, with the aim of identifying immunological markers of active-disease severity.

\section{ACKNOWLEDGMENTS}

We thank Thaise Yumie Tomokane for technical support.

\section{CONFLICT OF INTEREST}

The authors declare that there is no conflict of interest.

\section{FINANCIAL SUPPORT}

This work was supported by grant 2006/56319-1 from the São Paulo Research Foundation and HCFMUSP-LIM50. 


\section{REFERENCES}

1. Gontijo CMF, Melo MN. Leishmaniose visceral no Brasil, quadro atual, desafios e perspectivas. Rev Bras Epidemiol 2004; 7:338-349.

2. Dantas-Torres F, Brandão-Fillho SP. Visceral leishmaniasis in Brazil: revisiting paradigms of epidemiology and control. Rev Inst Med Trop Sao Paulo 2006; 48:151-156.

3. Ministério da Saúde. Secretaria de Vigilância em Saúde. Departamento de Vigilância Epidemiológica. Leishmaniose visceral: recomendações clínicas para redução da letalidade. Brasília: Editora do Ministério da Saúde; 2011.

4. Ministério da Saúde. Secretaria de Vigilância em Saúde. Leishmaniose visceral grave: normas e condutas. Brasília: Editora do Ministério da Saúde; 2006.

5. Alves JGB. Calazar. In: Figueira F, Ferreira OS, Bezerra-Alves JG, editors. Pediatria-Instituto Materno infantil de Pernambuco. $2^{\text {nd }}$ ed. Rio de Janeiro: Medsi; 1996. p. 320-327.

6. Elnour IB, Akinbami FO, Shakeel A, Venugopalan P. Visceral leishmaniasis in Omani children: a review. Ann Trop Paediatr 2001; 21:159-163.

7. Queiroz MJ. Fatores prognósticos associados ao óbito por leishmaniose visceral (calazar) em crianças Internadas no instituto materno infantil de Pernambuco. [Masters Dissertation]: [Recife]. Universidade Federal de Pernambuco; 2002.

8. Werneck GL, Batista MS, Gomes JR, Costa DL, Costa CH. Prognostic factors for death from visceral leishmaniasis in Teresina, Brazil. Infection 2003; 31:174-177.

9. Rey LC, Martins CV, Ribeiro HB, Lima AA. Leishmaniose visceral americana (calazar) em crianças hospitalizadas de área endêmica. J Pediatr 2005; 81:73-78.

10. Costa CHN, Werneck GL, Costa DL, Holanda TA, Aguiar GB, Carvalho AS, et al. Is severe visceral leishmaniasis a systemic inflammatory response syndrome? A case control study. Rev Soc Bras Med Trop 2010; 43:386392.

11. Sampaio MJ, Cavalcanti NV, Alves JG, Fernandes Filho MJ, Correia JB. Risk factors for death in children with visceral leishmaniasis. PLoS Negl Trop Dis 2010; 4:e877.

12. Goto H, Prianti MG. Immunoactivation and immunopathogeny during active visceral leishmaniasis. Rev Inst Med Trop Sao Paulo 2009; 51:241-246.

13. Carvalho EM, Johnson WD, Barreto E, Marsden PD, Costa JML, Reed $\mathrm{S}$, et al. Cell mediated immunity in American cutaneous and mucosal leishmaniasis. J Immunol 1985;135:4144-4148.

14. Duarte MI, Matta VL, Corbett CE, Laurenti MD, Chebabo R, Goto H. Interstitial pneumonitis in human visceral leishmaniasis. Trans R Soc Trop Med Hyg 1989; 83:73-76.

15. Marzochi MCA, Marzochi KBF, Schubach AD. Leishmaniose Visceral Americana (Calazar Americano ou Neotropical). In: Cimerman B, Cimermans, editors. Parasitologia Humana e seus Fundamentos Gerais. $2^{\text {nd }}$ ed. São Paulo: Atheneu; 2002. p.565-580.

16. Gama ME, Costa JM, Pereira JC, Gomes CM, Corbett CE. Serum cytokine profile in the subclinical form of visceral leishmaniasis. Braz J Med Biol Res 2004; 37:129-136.

17. Silveira FT, Lainson R, Crescente JA, Souza AA, Campos MB, Gomes $\mathrm{CM}$, et al. A prospective study on the dynamics of the clinical and immunological evolution of human Leishmania (L.) infantum chagasi infection in the Brazilian Amazon region. Trans R Soc Trop Med Hyg 2010; 104:529-535.

18. Silveira FT, Lainson R, Souza AA, Campos MB, Carneiro LA, Lima LV, et al. Further evidences on a new diagnostic approach for monitoring human Leishmania (L.) infantum chagasi infection in Amazonian Brazil. Parasitol Res 2010; 106:377-386.

19. Oliveira JM, Fernandes AC, Dorval MC, Alves TP, Fernandes TD, Oshiro ET, et al. Mortalidade por leishmaniose visceral: aspectos clínicos e laboratoriais. Rev Soc Bras Med Trop 2010; 43:2.
20. Braga AS. Fatores associados à evolução clínica da leishmaniose visceral em crianças hospitalizadas em centro de referência de Belo Horizonte, 2001 a 2005. [Thesis].[Belo Horizonte]: Universidade Federal de Minas Gerais; 2007.

21. Alvarenga DG, Escalda PM, Costa AS, Monreal MT. Leishmaniose visceral: estudo retrospectivo de fatores associados à letalidade. Rev Soc Bras Med Trop 2010; 43:194-197.

22. Convit J, Pinardi ME, Randon AJ. Diffuse cutaneous leishmaniasis: a disease due to an immunological defect of the host. Trans R Soc Trop Med Hyg 1972; 66:603-610.

23. Heinzel FP, Sadick MD, Mutha SS, Locksley RM. Production of IFN-g, IL-2, IL-4 and IL-10 by CD4+ lymphocytes in vivo during healing and progressive murine leishmaniasis. Proc Nat Acad Sci USA 1991; 88:7011-7015.

24. Goto H, Lindoso JA. Immunity and immunosuppression in experimental visceral leishmaniasis. Braz J Med Biol Res 2004; 37:615-623.

25. Nylén S, Sacks D. Interleukin-10 and the pathogenesis of human visceral leishmaniasis. Trends Immunol 2007; 28:378-384.

26. Bogdan C, Rollinghoff M, Diefenbach A. Reactive oxygen and reactive nitrogen intermediates in innate and specific immunity. Curr Opin Immunol 2000; 12:64-76.

27. Liew FY, Wei XQ, Proudfoot L. Cytokines and nitric oxide as effector molecules against parasitic infections. Philos Trans R Soc Lond B Biol Sci 1997; 352:1311-1315.

28. Pitta MGR, Romano A, Cabantous S, Henri S, Hammad A, Kouriba B, et al. IL-17 and IL-22 are associated with protection against human kala azar caused by Leishmania donovani. J Clin Invest 2009; 119: 2379-2387.

29. Nascimento MSL. Papel de linfócitos Th17 durante a infecção experimental por Leishmania infantum/chagasi. [Masters Dissertation]. [Ribeirão Preto]: Universidade de São Paulo; 2012.

30. Badaro R, Jones TC, Carvalho EM, Sampaio D, Reed SG, Barral A, et al. New perspectives on a subclinical form of visceral leishmaniasis. J Infect Dis 1986; 154:1003-1011.

31. Carvalho EM, Bacellar O, Brownell C, Regis T, Coffman RL, Reed SG. Restoration of IFN-gamma production and lymphocyte proliferation in visceral leishmaniasis. J Immunol 1994; 152:5949-5956.

32. Carvalho EM, Barral A, Pedral-Sampaio D, Barral-Netto M, Badaro R, Rocha $\mathrm{H}$, et al. Immunologic markers of clinical evolution in children recently infected with Leishmania donovani chagasi. J Infect Dis 1992; 165:535-540.

33. Holaday BJ, Pompeu MM, Jeronimo S, Texeira MJ, Sousa AA, Vasconcelos AW, et al. Potential role for interleukin-10 in the immunosuppression associated with kala azar. J Clin Invest 1993; 92:2626-2632.

34. D'Andrea A, Aste-Amezaga M, Valiante NM, Ma X, Kubin M, Trinchieri G. Interleukin 10 (IL-10) inhibits human lymphocyte interferon gammaproduction by suppressing natural killer cell stimulatory factor/IL-12 synthesis in accessory cells. J Exp Med 1993;178:1041-1048.

35. Nylen S, Murya R, Eidsmo L, Manandhar KD, Sundar S, Sacks D. Splenic accumulation of IL-10 mRNA in T cells distinct from CD4+CD525+ (Foxp3) regulatory T cells in human visceral leishmaniasis. 2007; J Exp Med 204:805-817.

36. Wilson ME, Jeronimo SM, Pearson RD. Immunopathogenesis of infection with the visceralizing Leishmania species. Mirob Pathog 2005; $38: 147-160$.

37. Gautam S, Kumar R, Maurya R, Nylen S, Ansari N, Rai M, et al. IL-10 neutralization promotes parasite clearence in splenic aspirate cells from patients with visceral leishmaniasis. J Clin Invest 2011; 204:1134-1137.

38. Asseman C, Mauze S, Leach MW, Coffman RL, Powrie F. An essential role for interleukin 10 in the function of regulatory $\mathrm{T}$ cells that inhibit intestinal inflammation. J Exp Med 1999; 190:995-1004.

39. Fehervari Z, Sakaguchi S. CD4+ Tregs and imune control. J Clin Invvest 2004; 114: 1209-1217. 